\title{
The Acting in Group of Teachers as Possibility of Resignification of the Interpretation about the Writing Language
}

\author{
Claudia Regina Mosca Giroto1,2, Rosane Michelli de Castro33, \\ Fabiana Cristina Frigieri de Vitta ${ }^{1}$, Joice Emanuele Munhoz Cicilino ${ }^{2}$ \\ ${ }^{1}$ Department of Especial Education, Faculty of Philosophy and Sciences (FFC), UNESP, Marília, Brazil \\ ${ }^{2}$ Department of School Education, Faculty of Science and Letters (FCLAR), UNESP, Marília, Brazil \\ ${ }^{3}$ Department of Didactics, Faculty of Philosophy and Sciences (FFC), UNESP, Marília, Brazil \\ Email: claudia.mosca@marilia.unesp.br, rosanemichelli@marilia.unesp.br, fabianavitta@gmail.com, \\ joicecicilino@gmail.com
}

Received 10 August 2014; revised 12 September 2014; accepted 6 October 2014

Copyright (C) 2014 by authors and Scientific Research Publishing Inc.

This work is licensed under the Creative Commons Attribution International License (CC BY). http://creativecommons.org/licenses/by/4.0/

(c) (i) Open Access

\begin{abstract}
Front of the possibility of acting with the teachers who teach in schools of Early Childhood Education for children aged six years, about the re-siginification of the understanding of writing language and of the importance of the child in this age group establish a positive relationship with this mode of language, was developed in 2011, a project linked to the Teaching of UNESP titled "Depathologization learning of the writing and inclusive education: reflections and actions of the teacher of Early Childhood Education". This project aims to identification of the actions, in the classroom, of the patologization and subsequent implementation of actions depathologization writing by teachers' actions, considering the increasingly early systematization of formal education of this kind of language in kindergarten. To this end, procedures that characterize the collaborative methodology are adopted. Throughout the methodological course, the engagement of the teachers, of the coordination and of the direction was valued, which seemed to favor both the formation, as the maintenance of the group, were very important aspects to ensure the interaction between its members and the common interest in the reflection about the topic in question. This paper focuses attention on whether thematic axes highlight during the initial survey of the expectations of teachers subsequently addressed in theoretical and reflective meetings leading up to identification of actions the patologization and/or of the proposition of the actions despatologizadoras of the learning of the writing, and in what refers to the way they are addressed.
\end{abstract}

\section{Keywords}

The Acting in Group, Teacher Formation, The Writing Language

How to cite this paper: Giroto, C. R. M., de Castro, R. M., de Vitta, F. C. F., \& Cicilino, J. E. M. (2014). The Acting in Group of Teachers as Possibility of Resignification of the Interpretation about the Writing Language. Creative Education, 5, 18341841. http://dx.doi.org/10.4236/ce.2014.520204 


\section{Introduction}

In 2011, the extension project "Depathologization learning of the writing and inclusive education: reflections and actions of the teacher of Early Childhood Education” was developed at the Nucleus for Teaching College of Sciences-FFC/UNESP, Marilia-SP-Brazil. The idea was develop, with the collaboration of teachers from kindergarten, reflections and actions of depathologization of the writing, so that the child of this age could experience a positive relationship with this type of language.

To this end, procedures that characterize the collaborative methodology were adopted: 1) Outline the expectations and needs of the participants, which included a personal interview, pre realization of the proposed activities, and a forum for discussion, guided by a previously prepared script used to identify aspects about writing that mobilized participants. In this condition, these aspects were understood as an initial reference for discussions subsequent triggered; 2) Theoretical-reflective meetings, conducted fortnightly and of the systematic form, used as possibility of obtaining data supplied by the teachers about the pedagogical discourse that directed the daily practics, with regard to the practice of pathologizing and/or of depathologization writing, since the value of this speech was considered relevant because they believed that, from the reflection on it was that the teacher would be able to envision the possibilities for modification of these practices, if deemed necessary; 3) Collaborative Intervention, held fortnightly, through which assumed relevance previously identified and defined daily practices as those directed to depathologization of literacy, and so permeated by motivational aspects, teaching relationships, classroom, recovery the self-esteem of the teacher and of the student, integrated collective action to school projects, textual analysis activities, training support group, among others; and 4) Analysis and dissemination of results through an interview, after completion of the activities, and other discussion forum, so as to enable the collective analysis of the results and the systematization of the reflective process of autonomous and collaborative intervention and emancipatory on the part of those involved, such as providing for the use of the collaborative approach.

The investment in the teacher-researcher relationship, from the perspective that there is no more important work than the other, but that both, with their knowledge and experiences can jointly contribute to the understanding of each other, as the writing language, as subsidized by the idea that:

“[...] The process of building relations and interactions that shape the story of a group, always singular, affects the particular history and the building not only the language but also-through it-in the constitution of the identity of each member of this group [...] in the sociolinguistic interactions relate to the positions and social roles assumed and performed in various social groupings in which the subject is inserted." (Panhoca, 2004: p. 1055).

The group was guided by the idea postulated by (Nemirovsky, 2002: p. 101) that "[...] as the teacher shows a genuine interest and enthusiasm for working on something in particular, will be promoting this attitude also may prevail, at least among most members of the group”. Therefore, throughout the journey undertaken by the actions contemplated by the project in question was valued the engagement of the teachers, coordination and direction, which seemed to encourage the formation and maintenance of the group, essential aspects to ensure interaction among its members and the common interest in the discussion about the topic in question (Zimerman, 1997; Panhoca, 2002).

Due to the diversity of actions developed through this project was particularized, in this text, the actions that originated for the thematic axes highlighted during the initial survey of the expectations of teachers subsequently addressed in theoretical and reflective meetings leading up to identification of actions of pathologization and/or the proposition of des-pathologization actions of literacy, and in regard to how they were addressed, namely: 1) literacy, literacy and schooling, Orality and literacy; 2) Relationship; 3) Design of the errors present in writing; 4) Production of texts and genres; and 5) The teacher's role as a mediator in the process of appropriation of the formal writing.

\section{Axis 1: Literacy, Initial Reading Instruction and Schooling}

During the interview pre-activities, and forum for initial discussion, the teachers generally had difficulties in discussing the concepts of writing language, literacy, initial reading instruction and schooling, having prevailed among such teachers the use these expressions in the condition synonyms, a situation that triggered the study of these concepts in theoretical and reflective meetings undertaken. 
Marcuschi (2001: p. 21) Argues that the term "literacy” should be used in the plural, because of the numerous and different literacy practices. Thus, the condition of literate entails effective participation in the literacy situations and not just the use of formal writing.

Correa (2000: p. 140) emphasizes, however, that the conception of literacy should go beyond this idea of varying degrees of a minimal type to a maximum. According to this author, this idea, although it represented a breakthrough in the understanding of issues related to initial reading instruction, the literacy presupposes the application.

Marcuschi (2001: p. 22) also emphasizes the importance of distinguishing literacy, initial reading instruction and schooling. Literacy is understood by him as a situation that does not necessarily have to occur in schools, but suppose subjected to teaching learning and mastery of the skills of reading and writing, while schooling is characterized as "[... ] formal and institutional practice of teaching aimed at a full student education, and initial reading instruction is just one of the tasks/activities of the school.”

Tfouni (1997) also proposes the distinction between literacy, initial reading instruction and schooling. Literacy is situated, by this author, on the social level, since it refers to the socio-historical aspects of the appropriation of writing. initial reading instruction characterizes the individual level (domain skills of reading and writing). Schooling, in turn, is linked to the formal instructional and teaching that takes place within the school. The confusion between such terms, also pointed out by other researchers, is considered by this author as a difficulty in understanding literacy, since this confusion commonly relates to the use of these terms as equivalent.

\section{Axis 2: Relationship between Orality and Writing}

The fact to have prevailed among teachers ideas that writing is orality and/or that only serves as a communication tool, rather than recovery of the conditions of use of writing, modes of production, seconded only by a few participants, instigated the discussion of concepts about writing language and its relationship to orality.

According to Marcuschi (2001), the idea that writing is orality can be justified by the predominance of grammatical view of writing as a direct representation of speech or the overlap of oral language in relation to writing, which gives for the writing a place secondary. Such a view, according to this author, does not seek to clarify the similarities and differences between orality and literacy and is justified, therefore, by considering the derivative of speech writing.

About it, this author points out that the supremacy of orality over writing occurs only on the chronological aspect, in relation to the time of emergence of both, which does not give the most prestigious for orality. Instead, the author emphasizes that, when considering the use of writing, can acquire greater than that allocated to the oral social value. This will depend on the context of use of these modalities of language, whose relationship must be understood in a continuum, because of the constant dynamic between them.

This author also distinguishes two dimensions in the treatment of spoken and writing language: the first would be the size of the social practices that involve oral and (s) literacy(s). The second, on the modalities of language use, include speech and writing. Thus, orality and literacy understand aspects broader than speaking and writing relationships, implying orality as a result of interactive social practice, based on various forms of oral discourse, and literacy as various social practices based on the use of writing.

For Marcuschi (2001: pp. 25-26), the speech turn “[...] production would be a way for text-discourse communicative purposes the oral mode (located in the plane of the oral)" while writing "[...] a mode of textual-discursive production for communicative purposes [...] and is characterized by its graphical constitution, though, also involves resources and other pictorial order", which would place in terms of literacies. It is much more process than product. Thus, writing can not be understood as a representation of orality, simply because she does not play varied phenomena of orality as prosody, gestures and body movements and gaze. Likewise, orality does not reproduce aspects of writing, such as size and font, colors and formats, among others. Both have their own characteristics, but these characteristics do not give them a position opposing or dichotomous linguistic systems.

Koch (2000) seems to agree with those statements, to also maintain that both the oral and the writing one feature characteristics, although both use the same linguistic system. According to the author, what happens is that there are situations in which the writing text is closer to the colloquial and situations in which the spoken text is closer to formal writing speech. We observe, therefore, that, to this author, the relationship between orality and writing is also determined by the different contexts of use of both. 
Tfouni (1997) argues that writing and orality are not in a relationship of dependence but interdependence, which determines the interplay between them, seems to reinforce that both should not be understood from the perspective of the dichotomy. However, according to this author, this relationship is conditioned by the position taken by the subject and author, who can now be given toward the oral to the writing, sometimes in the direction of writing to oral, depending on the context of use.

Koch (2000) also emphasizes the ability to be designed writing erroneously into an ideal pattern which speech departs. This fact, according to this author, may be justified by the fact that speech is often analyzed based on grammar designed for writing, which demands a jaundiced view of speech. This assumption can also strengthen the position of these two teachers (P1 and P15), which answers that left implicit.

Geraldi (1996), in this respect, believes that this need to search for cultural norms and prestige of orality stems from of the what he calls "regulation of speech", a consequence of a process of election of the prestigious standard determined politically and economically (the example the discussion in the introduction to this study).

For this author, the school is in a public forum in which the use of cultural norms are taught and required, from an idea of homogeneous and static language, ie the language understood only as code and the cultural norms as more adequate linguistic variety. This idea of understanding linked to the representation of a linguistic variety judged most suitable language may have contributed to the understanding of the teachers participating in this study, as the appropriation process of writing reduced to the appropriation of standard-educated variety, which implies stigmatizing way of speaking of their students and, indirectly, how to write well.

Franchi (1992) states that the distance between the student's way of speaking and cultured considered the norm is usually transformed into a problem, commonly located in the student, which contributes to the stigmatization of linguistic varieties, fleeing the cultured variety, occur and become standard. This author, as Geraldi (1996), does not disregard the importance of the role of schools in teaching cultural norms. Both point to the need for the school to prevent discrimination of linguistic varieties considered less prestigious, rather than mandatory replacement of these varieties by the use of cultural norms.

Likewise, also, pay attention to the importance of the teacher in the ownership of the writing process, because it should reflect more about the similarities and differences between orality and writing and prevent prejudice and discrimination from both their way of speaking students talk about the interference of this writing. These authors also consider that a conception of writing that this is not only understood as code or acquires a higher value to the speech, but understand that both relate to the circumstances in their uses, among other factors, will enable teacher to assist students not only in appropriating the orthographic conventions, but mainly in the settlement of the conflicts that such use may result, without, however, transform these conventions in the only acceptable and correctly (Franchi, 1992; Geraldi, 1996). Based on these assumptions, it is possible to admit that both the oral and the writing one has specificities that are distinct in terms of the language that influence each other, and understanding of such crucial specifics to combat the idea of writing as a representation of speech.

\section{Axis 3: Errors Present in Writing: Problems or Solutions?}

Invariably, teachers referred to the errors present in graphic productions of his students in the beginning the formal process of appropriation of writing, as symptoms of diseases. Under such an understanding, show excessive concern with the issue of diagnosis of learning difficulties of writing they have identified in their students. This situation then sparked deepening of the theoretical-reflective meetings, the study on the understanding of the nature of these errors.

Abaurre, Fiad, \& Mayrink-Sabinson (2001c) argue that the so-called "errors" present in the writing production of the student, especially early grades, are actually clues that reveal the route of the student in the appropriation process of writing a since these signs are characterized by situations of conflict experienced by him.

These indications, as explained by Abaurre (2001a), translated into signals of constant reworking activities marking its provisional character. For this author, such evidence also reveal the differences experienced by the subjects, as the learning of writing, these differences determined by the particular history of each subject with language. Nevertheless, the criteria used by the child are not always understood by the adult, which may involve the characterization of the evidence preparation and reworking, in the text, as errors. So, according to what this author says, we can consider that this evidence, interpreted as errors can give rise to the establishment of a situation considered pathological when, in fact, she is absolutely positive and desired.

The occurrences of such evidence, trademarks present in the students' texts reveal, exactly, the ability of reflection mentioned by the authors, which agrees with Silva (1991). This author asserts that such evidence-marks 
indicate such capacity, characterize the performance of the child on writing and do not represent in any way, a pathological manifestation.

This position is also reinforced by Possenti (2002), who emphasizes that when such errors do not exceed the field of linguistic variation and practice of writing and are therefore not diseases.

About this question, Berberian (2003) highlights the importance of the criteria used in assessment situations writing production. This author justifies his concern when using the assumption that the conception of writing that prioritizes the grammatical aspects is which constitutes the most important factor for the transformation of different occurrences of the official spelling errors and, consequently, in pathologies. Thus, in addition to the child's experience with different contexts of use of writing, the possibility of performing speculations about possible questions you may submit writing on the representation of particular relevance in establishing his identity as author and reader.

The concern of these authors may refer to what Luria (1988) proposes, as to which the act of writing precedes their understanding and therefore the domain of ability to write not involves an understanding of writing. Thus, one can understand that the student is at the beginning of formal contact with the writing should be able to experiment with different possibilities about these occurrences.

Thus, the inability to be institutionalized, because of the evidence that the learner has not yet appropriated the orthographic conventions, and instituting a diagnosis of learning disabilities or reading and writing certainly departs from this understanding of learner the function of writing. This is due to the mechanistic and reductionist conception of writing language contributes to the school to continue assigning responsibility for that failure in the student. This, in turn, follows their school career enhancing such responsibility to the point of considering incapable as author-reader-interlocutor.

Abaurre (2001b) states that the solutions that the child seeks to interpret such an occurrence are subject often to local solutions, which will not necessarily be systematized, which requires the greatest teacher concern about the conditions of production of the text, which can to explicit the criteria used by the child in the search for solutions to your questions in relation to writing.

\section{Axis 4: Production of Texts and Textual Genres}

Based in the critical to procedures used for the production and interpretation of text that are based in the letter, in the syllable in the word or the phrase, since such procedures differ from the discursive competence of the student, i.e., the responsibility for the production of discourse, whether oral, are writing and tailored to the enunciative situations, the text can be understood during discussions undertaken by and with teachers about this thematic area, as a result of interaction, whose meaning is constructed from the text itself, which implies the existence of varied meanings, determined by such interaction and context of use, rather than the establishment of a single possible meaning (Fávero, 1995; Koch, 1995, 2000, 2001; Koch \& Travaglia, 1996).

In the words of Travaglia \& Koch (1996: p. 25): “[...] The meaning is not in the text, but is built from it [...] a text is constituted as such at the time that partners are in a global communicative activity [...] "are able to build for her a sense.

This way of understanding the text implies a placement of not more directed to the teaching of a mechanical model of text (often the model used by the school), in which the occurrence of various senses is not designed, since the prevailing sense given by the teacher in the teaching situation, ie, what he considers to be the correct interpretation.

Lacerda (1995) highlights the importance of the text, considering that it is the language that manifests as Berberian (2003) treats the text as the center of the teaching-learning. That way process, makes it appropriate to highlight the importance attributed the production of texts, by virtue of such production reflect the interactions between student-teacher or as called Koch (2001), among interactants.

Before the defense that the teacher should be one of the mediators of the process of appropriation of writing is quite possible the assumption that he, too, is responsible for using various means to enable its students to consider, in the activity of text production: who, how, where, to whom, when and why to produce a text (Smolka, 1988). Undoubtedly, understanding, by students, about these issues (who, how, where, to whom, when and why to produce a text) could facilitate their understanding in relation to their role as player/producer of text. This consideration determines the need for choice by the student, among other things, the different speech genres.

The use of genres as tools for the construction of discourse and language in general, is presented by the Na- 
tional Curricular Parameters-PCN, which emphasize the different genres used for writing texts are considered units of curricula and progressions in elementary school.

Authors draw attention to the fact that the school in an attempt to employ genres as tools for the field of language production, fails to understand that the production of a text is influenced by socio-historical and ideological factors that determine their production conditions. When trying to regulate this production, the school ultimately disregard such factors, since not all the conditions that lead to the use of a genre can be played in the school context.

The adoption of a particular genre, in school, according Schneuwly \& Dolz (2004), turns out to make it a "school genre", a variation of the genre of origin (an instrument other practices of simulated language in the classroom ). These authors criticize the attitude of the school to use this genre not as a tool that favors the appropriation of language, but as the object of teaching and learning, disconnected from authentic communication situations and dependent on social practices. Is this descontextualization that makes it an educated genre, as it is characterized as a representation of the real model, created by the school, in the pursuit of teaching "modeling" of school genres.

Given the comments Rojo \& Cordeiro (2004) and Schneuwly \& Dolz (2004), is a frequent concern of teachers with the "modeling" of the text to be produced by the students, i.e., with the production of a text as what they consider a "good text".

Another aspect to be considered relates to asymmetric-sided situation established in the classroom, in the production of texts schooled genres, in which the teacher, by proposing training of a standard model, does not allow the participation of the student in choosing the kind to be used. Thus, when such permission occurs, this is linked to the fact that students follow step-by-step recommendations of the teacher, which should result in a deemed appropriate text model, and a particular model of gender, often decontextualized social practices outside the school.

Promoting the use of one or another particular genre is necessary, however, what is observed is that teachers often end up limiting the opportunities that students might have when comparing the possibilities of use of different genres that can serve to the elaboration of texts.

The only alternative for the student to ensure that your text is considered "good", therefore, is to follow the roadmap set by his teacher because deviate from this script does not imply creativity, possibility of new interpretations, assigning new meanings instead can take you under this distorted interpretation, the condition of disability.

\section{Axis 5: The Teacher's Role as a Mediator in the Process of Appropriation of the Formal Writing}

Forward to the discussion that involved the topics previously mentioned, teachers demonstrated special interest to define and better understand the role they occupy in the establishment of a more positive relationship between the child who is in his early schooling of the formal writing language. In this sense, after planning about how this issue should be addressed have, collectively, the option for discussion about the status of teachers as interlocutor and mediator of the situations in the classroom that require graphic productions of any kind.

The interaction in the classroom, according to Smolka (2000: p. 45), is crucial to that writing is characterized as establishing of relationships that can be understood as discursive moment and not merely as an object of knowledge.

In considering, therefore, the interaction and dialogue (which obviously can not be reduced only to school situations and, more specifically, to the classroom) as determinants for the construction of writing, the role of the teacher acquires great relevance in position of text output. This paper refers to the place he occupies as an interlocutor, i.e., as the other (in this case, the literate adult), in relation to their students, since the role of the other also becomes constitutive of the process of appropriation writing because the literate adult plays as significant, the child's actions with writing (De Lemos, 1982).

Mairynk-Sabinson (2001) reinforces this idea when also features the other, literate adult, as one who works in the process, to assign meaning to the actions of the child with the writing object, from the interactional practices that engage both. The constitution of such practices allows the child to the construction of the significance of writing. This interplay of literate adults and children, in the initial phase of appropriation of writing, enables, with the exchange of experiences, both can move each of its respective place, at certain times, take the place of one another. 
This interference is emphasized by Rojo (1994: p. 13), preface to the study of Daudén (1994), which examined the role of the other, in the case of father and mother, as relevant to the constructions of literacy of the child (whose analysis certainly can be applied to the role of the teacher.

Thus, it is crucial the role of the teacher as the introduction of interactive situations that contribute to the process of appropriation of writing.

This mediation determines the understanding that the teacher must allow the student, developing hypotheses about writing, besides assigning relevance to the marks left in the texts. Taking such an approach does not mean leaving aside the work with the orthographic conventions, as well as features not condoning the error.

Mayrink-Sabinson (2001), commenting on the ways in which the other (party-reader) leaves marks on the child writing, underlines the importance of the models offered by such other writing and direct interference, for he held this writing, through oral comments.

Obviously, the process of appropriation of writing depends not only on teacher mediation, as this process begins even before formal schooling. However, interlocutive relationship between teacher and student is critical so it has better able to understand the possibilities of real language use. Therefore, the preoccupation with the formal aspects can also support the idea that the teacher often still attached to a model that considers ideal text, which its students can not distance himself. Thus, under such a concern, the teacher, more than you put on the role of mediator, takes upon himself, as shown by Smolka (2000: p. 36), the "[...] task of teaching established by the school." According to this author, this task assumes that the teacher starts from a position in which he seizes the knowledge (who believes he has) and passes to the student as to condition yourself to think this natural practice of transmitting knowledge by the teacher. This position implies, then, in the words of this author, a linear, one-sided and static relationship and a monopolization of space in the classroom, the teacher, because what predominates is his speech that, in turn, determines the idea that knowledge is only acquired at school. Therefore, interlocutivas situations do not constitute, in fact.

Smolka (2000, p. 36) identifies, by virtue of this position, the transmission of knowledge, assumed by the teachers as to how they interpret the act of teaching and the act of learning: "[...] the act of teaching is characterized and reduces to speak and to point out the error; the act of learning is characterized by trying to copy and the silence.” The teaching of writing, in this view, comes down to technique, since the writing itself is understood as technical and meaningless, at school, there is a greater appreciation of the formal aspects of writing, to the detriment of the discursive aspects. According to this author, the opposite should occur: breaking the standard of teaching based on the transmission of knowledge, the linearity and one-sidedness, that such a pattern is replaced by the relationship between teacher and student, interlocution, which includes in this case, the joint construction of knowledge. This position then follows the definition of writing built by this author: writing as a discursive moment, as interaction and dialogue present in the context of the classroom.

\section{Brief Conclusions}

To conclude, we present aspects of the considerations made by the teachers during and immediately after the close of the theoretical-reflective meetings, registered in their diary field, about the dynamics surrounding the creation and functioning of the group consisting, based on partnership between researchers and teachers, and assistance provided for coordination and direction of the school, showed that all teachers involved felt that there was a greater professional integration, with the exchange of information and teaching strategies utilized in other situations, with all students of their respective classrooms.

The teachers also mentioned how the group worked with the exchange between teachers, strategies and materials, favored performance in the classroom, with students who believed, mistakenly, before participating in the project, such as those who had problems with the formal appropriation of writing.

Another aspect highlighted by all teachers was the rescue of confidence in the work itself. According to these teachers, the solutions discussed collectively adopted by them in the classroom, strengthened as it became aware that, despited the participation of researchers in the organization of the group, most of the changes were proposed and conducted by them. Thus, awareness of the capacity for understanding and solving the difficulties of the students, once deemed pathological symptoms, determined the change in expectations and judgments about these students. It was noteworthy that, as reported by teachers, some students initially judged as students with reading and writing problems were later considered by these same teachers as good students since come to understand, minimally, the nature of the errors made by such students in their graphic productions. 
Still, we emphasize that the reports of teachers revealed the importance they began to assign them, as one that assists in assigning meanings to writing, as they began to consider the singularities involved in the process of appropriation of the writing.

\section{References}

Abaurre, M. B. (2001a). Os primeiros sinais. In M. B. Abaurre, R. S. Fiad, \& M. L. Mayrink-Sabinson (Eds.), Cenas de aquisição da escrita: O sujeito e o trabalho com o texto (2nd ed., pp. 175-184). Campinas, SP: Mercado de Letras.

Abaurre, M. B. (2001b). Dados da escrita inicial: Indícios de constituição da hierarquia de constituintes silábicos? In C. L. M. Hernandorena (Ed.), Aquisição de língua materna e de língua estrangeira: Aspectos fonético-fonológicos (pp. 63-85). Pelotas: EDUCAT.

Abaurre, M. B., Fiad, R. S., \& Mayrink-Sabinson, M. L. (2001c). Em busca de pistas. Cenas de aquisição da escrita: O sujeito e o trabalho com o texto (2nd ed., pp. 13-36). Campinas, SP: Mercado de Letras.

Berberian, A. P. (2003). Princípios norteadores da avaliação clínica fonoaudiológica de crianças consideradas portadoras de distúrbios de leitura e escrita. In A. P. Berberian, G. A. Massi, \& A. C. Guarinello (Eds.), Linguagem escrita: Referenciais para a clínica fonoaudiológica (pp. 11-38). São Paulo: Plexus.

De Lemos, C. T. G. (1982). Sobre aquisição da linguagem e seu dilema (pecado) original. Boletim da Abralim, 3.

Franchi, C. (1992). Linguagem: Atividade constitutiva. Cadernos de Estudos Linguísticos, Campinas-SP, 22, 9-39.

Geraldi, J. W. (1996). Convívio paradoxal com o ensino de leitura e escrita. Cadernos de Estudos Linguísticos, Campinas-SP, 31, 127-143.

Koch, I. V. (1995). Aquisição da escrita e textualidade. Cadernos Cedes, 29, 109-117.

Koch, I. V. (2000). O texto e a construção dos sentidos. São Paulo: Contexto.

Koch, I. V. (2001). A coesão textual (15th ed.). São Paulo: Contexto.

Koch, I. V., \& Travaglia, L. C. (1996). A Coerência Textual (7th ed.). São Paulo: Contexto.

Lacerda, C. B. F. (1995). Inter-relação entre oralidade, desenho e escrita: O processo de construção do conhecimento. São Paulo: Cabral Editora.

Luria, A. R. (1988). O desenvolvimento da escrita na criança. In L. Vygotsky, A. R. Luria, \& A. N. Leontiev (Eds.), Linguagem, desenvolvimento e aprendizagem (pp. 143-189). São Paulo: Ícone Editora.

Marcuschi, L. A. (2001). Da fala para a escrita: Atividades de retextualização (3rd ed.). São Paulo: Cortez.

Mayrink-Sabinson, M. L. T. (2001). O papel do interlocutor. In M. B. Abaurre, R. S. Fiad, \& M. L. Mayrink-Sabinson (Eds.), Cenas de aquisição da escrita: $O$ sujeito e o trabalho com o texto (2nd ed., pp. 117-151). Campinas, SP: Mercado de Letras.

Nemirovsky, M. (2002). O ensino da linguagem escrita. Porto Alegre: Artmed.

Panhoca, I. (2002) O grupo terapêutico fonoaudiológico e sua articulação com a perspectiva histórico-cultural. In C. B. F. Lacerda, \& I. Panhoca (Eds.), Tempo de Fonoaudiologia III (pp. 15-24). Taubaté: Cabral.

Panhoca, I. (2004) Grupo terapêutico-fonoaudiológico: Refletindo sobre esse novo fazer. In L. P. Ferreira, D. M. Beffi-Lopes, \& S. C. O. Limongi (Orgs.), Tratado de Fonoaudiologia (pp. 1054-1058). São Paulo: Roca.

Possenti, S. (2002). Sobre a natureza dos erros, especialmente os de grafia. In A. C. B. Lodi, K. M. P. Harrison, \& S. R. L. Campos (Org.), Letramento e minorias (pp. 27-46). Porto Alegre: Mediação.

Rojo, R. H. R. (1994). Prefácio. In: A. T. B. C. Dauden (Org.), A criança e o outro na construção da linguagem escrita. São Paulo: Pancast.

Rojo, R. H. R., \& Cordeiro, G. S. (2004) Apresentação: Gêneros orais e escritos como objetos de ensino: Modo de pensar, modo de fazer. Gêneros orais e escritos na escola (pp. 7-20). Campinas, SP: Mercado de letras.

Schneuwly, B., \& Dolz, J. (2004). Os gêneros escolares: Das práticas de linguagem aos objetos de ensino. In R. Rojo, \& G. S. Cordeiro (Eds.), Gêneros orais e escritos na escola (pp. 71-91). Campinas, SP: Mercado de Letras.

Silva, A. (1991). Alfabetização: A escrita espontânea. São Paulo: Contexto.

Smolka, A. L. B. (1988). A criança na fase inicial da escrita: A alfabetização como processo discursivo. Campinas: Ed. da UNICAMP.

Smolka, A. L. B. (2000). A criança na fase inicial da escrita: A alfabetização como processo discursivo (9th ed.). Campinas: Cortez.

Tfouni, L. (1997). Letramento e alfabetização. São Paulo: Cortez. 
Scientific Research Publishing (SCIRP) is one of the largest Open Access journal publishers. It is currently publishing more than 200 open access, online, peer-reviewed journals covering a wide range of academic disciplines. SCIRP serves the worldwide academic communities and contributes to the progress and application of science with its publication.

Other selected journals from SCIRP are listed as below. Submit your manuscript to us via either submit@scirp.org or Online Submission Portal.
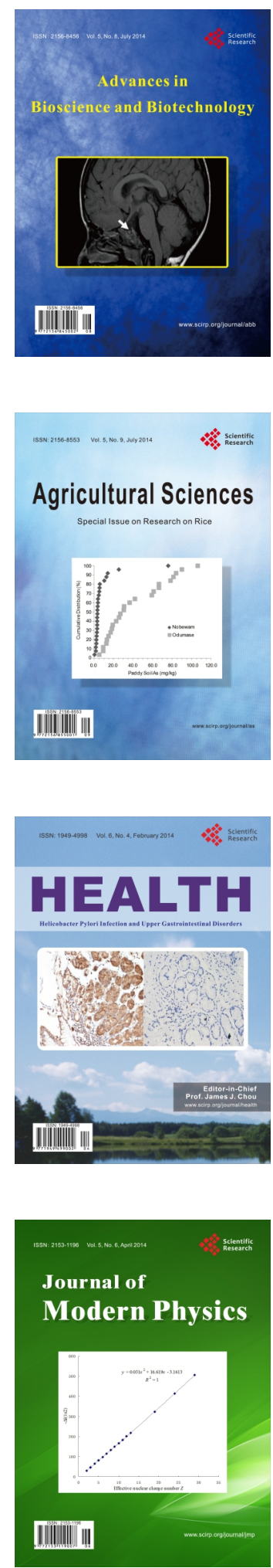
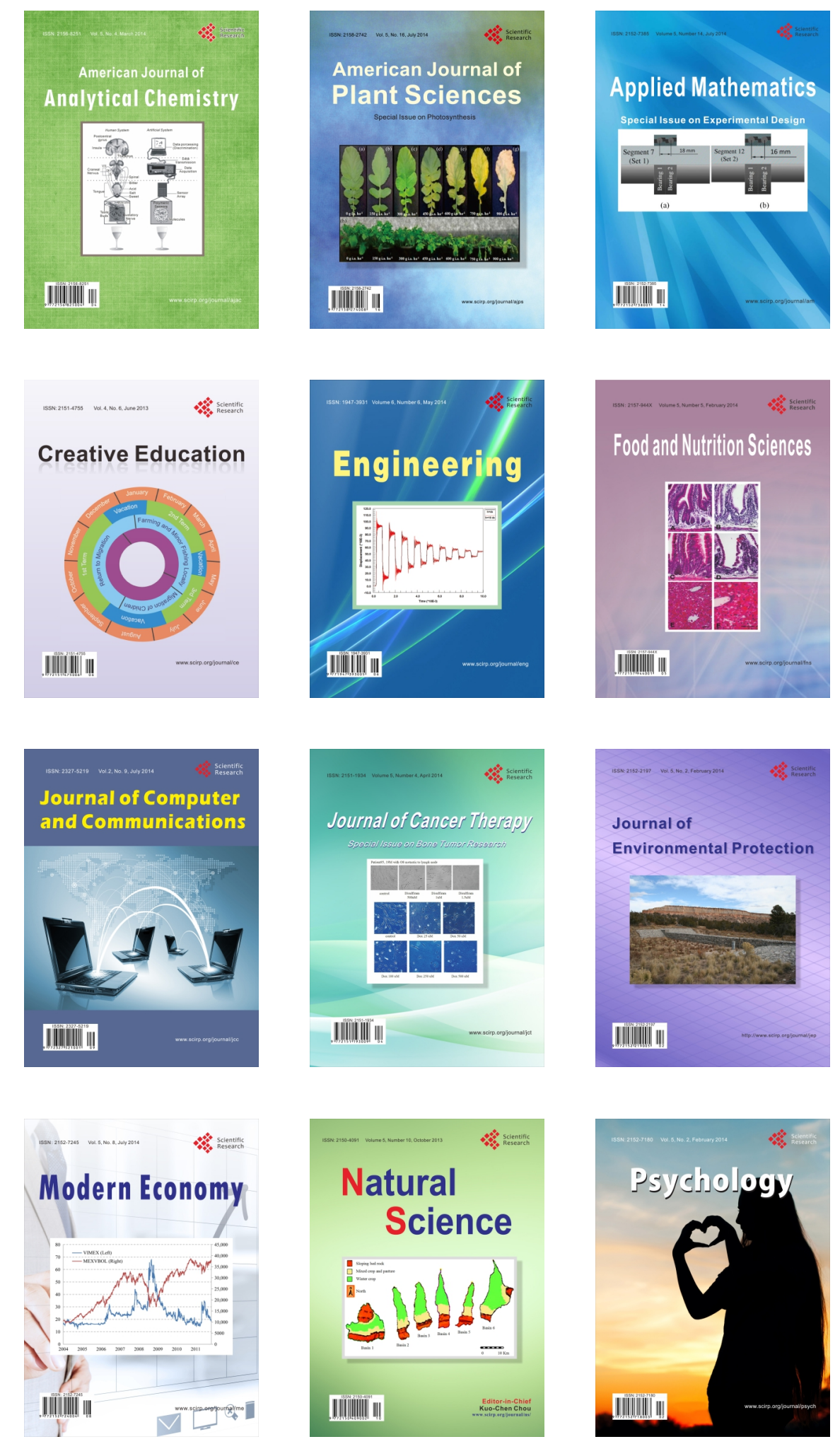